Article

\title{
Starring Dante
}

\author{
Albert Russell Ascoli
}

Italian Studies, University of California, Berkeley, CA 94720, USA; ascoli@berkeley.edu

Received: 2 April 2019; Accepted: 4 May 2019; Published: 13 May 2019

check for updates

\begin{abstract}
This essay offers an example of a guiding thread in my own research on and teaching of Dante's Commedia. Specifically, I will follow a strand that leads us from Dante's encounter with the "bella scola" of classical poets in Inferno Canto 4, through a key scene in the Purgatorio where Dante and his guide Virgil meet the late classical poet Statius, to the remarkable six-canto suite in the Heaven of the Stars, sign of Gemini, in which Dante-poet has Dante-character undergo a series doctrinal tests on the theological virtues. His successful response to the challenges posed by the apostles Peter, James, and Paul doubly authorizes him as poet and as Christian teacher of the highest order. These unique experiences as Dante is successively introduced to and made part of a rising series of elite groups, highlights his double role as humble student and prospective teacher of others. Among the various aims of this essay is to give a sample of a way in which teachers of the Commedia may address the perennial pedagogical problem of how to account for the extraordinary spectacle of a first-person epic that at once expresses deep piety with profound "charitas" (spiritual love) and appears as the absolute height of a self-aggrandizement seemingly inconsistent with Christian humility. Another is to suggest one possible strategy for teaching the Comedy as a whole, and especially the final canticle, the Paradiso, which even Dante himself notoriously thinks is "not for everyone".
\end{abstract}

Keywords: Dante; Commedia; Inferno; Purgatorio; Paradiso; theology and poetry; medieval astrology

It would hardly be an exaggeration to say-at a time when in many parts of the country and in so many institutions, the teaching of the humanities, and of literature in particular, and even more in particular the historical past, has suffered terribly - that the enduring power of certain authors-Dante, Shakespeare, Cervantes-to capture the imagination of students and the general public alike seems ever more precious, even as it becomes more precarious. And this is especially true for a work such as the Commedia (hereafter given as Divine Comedy), built on Dante's profound religious faith and his commitment to teaching it, which has appealed to a great many readers from the broadest possible spectrum of cultural backgrounds and world views-Catholic and Protestant-Christian and non-Christian alike-from Florence to Birmingham to Tokyo.

In this essay, I offer an example of a guiding thread in my own research on and teaching of Dante's great poem. ${ }^{1}$ Specifically, I will follow a strand that leads us from Dante's encounter with the

1 The number of pedagogical resources for the teaching of Dante has expanded exponentially over the last decades as dantisti (Dante scholars) have made increasing use of the technological possibilities afforded by the internet, at the same time as the number of hard-copy translations of the works, of biographies, and of volumes devoted explicitly to pedagogy have also multiplied. The Dante Society of America website provides an extensive if not complete list of links to many of the most useful sites currently available https://www.dantesociety.org/education-and-outreach, as well as access to the bilingual bibliographical resource know as the Bibliografia Internazionale Dantesca/International Dante Bibliography (http://dantesca.ntc.it/dnt-fo-catalog/pages/material-search.jsf) [to use the English-language version of the latter site, click on the EN icon in the upper-right]. The forthcoming volumes on approaches to teaching the Divine Comedy, edited by Christopher Kleinhenz and Kristina Olson, and published by the Modern Language Association, will be another extremely useful resource, as, I believe, will the special issue of Religions in which this essay finds itself. Still very useful, however, is (Jacoff 2007). 
"bella scola" of classical poets in Inferno canto 4, through a key scene in the Purgatorio where Dante and his guide Virgil meet the late classical poet Statius, to the remarkable six-canto suite in the Heaven of the Stars, sign of Gemini, in which Dante-poet has Dante-character undergo a series doctrinal tests on the theological virtues. His successful response to the challenges posed by the apostles Peter, James, and Paul doubly authorizes him as poet and as Christian teacher of the highest order. These unique experiences as Dante is successively introduced to and made part of a rising series of elite groups, highlights his double role as humble student and prospective teacher of others. Among the various aims of this essay is to give a sample of a way in which teachers of the Divine Comedy may address the perennial pedagogical problem of how to account for the extraordinary spectacle of a first-person epic that at once expresses deep piety with profound "charitas" (spiritual love) and appears as the absolute height of a self-aggrandizement seemingly inconsistent with Christian humility. Another is to suggest one possible strategy for teaching the Comedy as a whole, and especially the final canticle, the Paradiso, which even Dante himself notoriously thinks is "not for everyone."

First, however, I'd like to speak briefly about my own "subject position" as a non-Christian scholar-teacher of the greatest of Christian poets (with due deference to Milton's similar claims to that title). I originally came to study Dante as a point of convergence between two different life-paths, one vocational, one familial. The first was my fascination during my college years with the poetry of T.S. Eliot, whose famous pronouncement on the post-classical Western Canon, "Dante and Shakespeare divide the modern world between them; there is no third," ${ }^{2}$ was reflected as well in a web of Dantean allusions in his poetry, all of which finally led me to read Dante for the first time under the guidance of Professor Angelina Pietrangeli at the University of Illinois, Urbana-Champaign. The other was a will to explore my own Italian heritage: my Italian-Jewish heritage I should say-and add that my father and his family were refugees from the racial laws propagated by Mussolini's fascist regime on the eve of the Second World War. My initial attachment to Dante then was cultural and literary, not religious in any recognizable sense. And though the person with whom I studied Dante for my Ph.D., Giuseppe Mazzotta, was and is a practicing Catholic, deeply invested in what he has at different moments called the "theology of history" and theologia ludens of the Divine Comedy, ${ }^{3}$ my religious orientation remained unaltered, though of course I learned a great deal, though never enough, about Christianity, especially medieval Christianity, in the process. I would say as well that, on the whole, my students-at Cornell, at Northwestern, and now at Berkeley — have collectively been of a secular orientation. Or, at least, most of them knew very little about the Bible and the beliefs and practices of Christianity in its long history and many diverse forms. Of course, from time to time one or two students would come pre-endowed with some real knowledge of Christianity and its texts and they would always be a welcome addition, as I tried to explain the various concepts indispensable for even a rudimentary understanding of a poet whom Robert Hollander plausibly defined as a "theologus-poeta" and who from time to time has been accused of having attempted to write a Third Testament. ${ }^{4}$ I imagine that many of those issue of

2 (Eliot [1929] 1964).

3 For the first phrase see (Mazzotta 1979), for the second his Dante's Vision and the Circle of Knowledge (Princeton: Princeton University Press, 1993), (Mazzotta 1993, chp. 11). More recently, he has published a guide to his teaching of the poem, through Yale Open Courses series, as Reading Dante (Mazzotta 2008). See also the related lecture series at https://oyc.yale. edu/italian-language-and-literature/ital-310.

4 (Hollander [1976] 1980); see also his, (Hollander 1969). On the Commedia as "third Testament," see Gerhard Regn (Regn 2007, pp. 167-85), who is building on (Kablitz 1999). North American Dante criticism, much of it following in the wake of Charles Singleton, Hollander, and others, has been largely "theological" in orientation, though it is theology seen from an abstracting secular perspective, and most often concerned with the implications of Dante's eschatological vision for his concept of himself as poet. Variations of this theme can be found in scholars as varied as John Freccero, Teodolinda Barolini, Amilcare Iannucci, Christian Moevs, Peter Hawkins, Lino Pertile, Guy Raffa, Mary Watt, Matthew Treherne, Vittorio Montemaggi, Claire Honess and many others. A second and generally related strand of North American and anglo-phone criticism has been the study of Dante's appropriation and rewriting of classical authors whom he absorbs and subsumes into a Christian vision of cultural history (Hollander, Mazzotta, Barolini, Ronald Martinez, Winthrop Wetherbee, and Zygmunt Baranski are among many strong voices in this line of study). Despite the general importance of Erich Auerbach's work in English, until recently the notion of "Dante, Poet of the Secular World" and of Dante as key player in the founding of the Western tradition of mimetic realism (Mimesis: "Figura") has had relatively little echo, though (Barolini 1992), and 
Religions and this essay in particular, face a rather different problem - whether specifically teaching Dante from their own faith-based perspective and/or introducing him to students with considerable knowledge of the Bible and the Christian traditions.

Let me give a rudimentary example of what I conceive of as a possible difference in the attitude of secular and Christian students confronting the Divine Comedy for the first time, and in particular the relationship of master and pupil established between Dante and Virgil in the very first canto, which concludes with the Roman poet's sudden disappearance just as Dante is about to encounter Beatrice in the earthly paradise 63 cantos later. For most of the students I have taught, a basic question that arises is "why didn't Dante save Virgil?", on the assumption that human affection and admiration alone should be the guiding principle in what for them is basically a work of science fiction, with "salvation" as the necessary happy ending to a narrative. ${ }^{5}$ For a Christian student, an earlier question might have been: why is Dante being guided by a pagan poet whose epic Augustine dismissed as the epitome of the diabolical City of Man in his Civitas Dei (City of God)? Such a student would also probably be more inclined to wonder why Dante thought he could save or damn anyone, much less Virgil in particular, and perhaps even to be puzzled at his hubris in claiming to reveal the truth of the after-life. In fact, it often seems to me that Dante has something to confuse and offend virtually every Christian sect. For Catholics, just for starters, there is his habit of damning popes whose politics and spending habits he disagreed with (notably in Inf. Canto 19)—or, perhaps more ironically still, presenting us with a one-time pope in Purgatorio Canto 19 who only converted to Christianity after he assumed the papal mantle. ${ }^{6}$ He also offers a powerful critique of the taking of vows in the early cantos of Paradiso, which might seem to anticipate Luther's views articulated some two centuries later. Such things, of course, quite endeared him to Protestant reformers, who, on the other hand, had to deal with his claims to extraordinary access to God's plan, his penchant for leaning on what Luther called the "Aristotelian Church," his insistence that the Papacy—when properly led—was indeed the spiritual center of Christianity, his belief that there is such a place as Purgatory (indeed his central place in creating its iconography), ${ }^{7}$ his celebration of prayers as "works" capable of hastening the access of souls to Heaven, his attachment to the cult of Mary, not to mention the whole idea of Beatrice's role in his own apparently assured salvation.

Whatever the orientation of student and teacher, however, the central problem of reading the Divine Comedy is bound to be the figure of Dante himself, as the character present from beginning to end of the poem, as the witness to the eschatological destinies of a wide range of memorable damned, purging and sainted souls, as a poet moving toward a complex of spiritual experience, knowledge, and poetic creativity that will permit him to compose the "sacro poema" or "sacred poem" (Paradiso 25.1), in which he then will "star." ${ }^{\prime \prime}$ In Canto 2 of Inferno (lines 13-33), the pilgrim compares the journey he is about to undertake to two famous precursors believed to have traveled to the other world-Aeneas, the Virgilian and Roman hero who descends into the underworld, past the realm of the damned and onto

later writings, and the work of (Ascoli 2008, 2013). A sharper focus on the political-social side of Dante's work, much more common in Italy, where the Commedia's character as "national poem" is in the foreground, has been generally lacking, though the recent books of Justin Steinberg (Steinberg 2007, 2013) and Alison Cornish (Cornish 2011) offer examples of a new and different direction.

5 On this endlessly repeated question, see, for instance, (Barolini 2006, chp. 7). The literature on Dante and Virgil is immense. Among the most influential voices have been Hollander, (Hollander 1983); Mazzotta, "Virgil and Augustine," in "Vergil and Augustine," chp. 4 in Dante, Poet of the Desert; (Barolini 1984, pp. 201-56), as well as a number of the essays in (Jacoff and Schnapp 1991). See also Ascoli, Dante and the Making, esp. pp. 307-57. See also notes 14-16 below.

6 Ascoli, Dante and the Making, esp. pp. 345-48.

7 (Le Goff 1986).

8 Both the Italian and English are cited, here and throughout, from The Divine Comedy of Dante Alighieri, 3 vols., ed. and trans. Robert M. Durling; comm. Robert M. Durling and Ronald L. Martinez; illus. Robert Turner (Oxford and New York: Oxford University Press, 1996 [volume 1: Inferno], 2003 [volume 2: Purgatorio], 2011 [volume 3: Paradiso]). (Durling [1996] 2011). Occasional emendations to the translation are marked in the text with brackets.

9 As with most of the topics taken up in this essay, the literature on the interplay between the two " $\mathrm{I}$ " character and narrator-of the Commedia is vast. The most influential version of the Dantean dyad is that of (Contini [1957] 1976), cogently developed by (Freccero 1986, chp. 1), in relation to the autobiographical model of St. Augustine's Confessions. 
the home of the blessed, and Saint Paul, who by his own cryptic words in 2nd Corinthians (12: 1-7), was rapt into "the third heaven," though in the body or not he declines to say. As generations of readers have recognized, when the pilgrim declares "io non Enëa, io non Paulo sono" (2.32; I am not Aeneas, I am not Paul), he both expresses due humility and, tacitly, prepares us for a journey, and a poem recounting it, that go far beyond Virgil and his hero, and indeed beyond Paul himself, at least in the comprehensive detail with which he will record his experience.

In teaching the Divine Comedya, the two most common strategies for tracking Dante's experience are to focus on his interactions with the souls of the three realms-the ways in which his reactions to them index his own fears and possibilities-and to chart his relationship with his three guides, Virgil, Beatrice, and, in the very last cantos, St. Bernard of Clairvaux. And of course for a complex of reasons, courses on the Divine Comedy, when they get out of Hell at all, tend to dedicate an inversely proportional amount of time and energy to the other realms (say, on Berkeley's 14 week semester, 8 to Hell, 4 to Purgatory, and 2, if that, to the Paradiso). The temptation to burrow into the most fascinating episodes and characters (Francesca and Paolo [Inf. 5], Brunetto Latini [Inf. 15], Ulysses [Inf. 26], Ugolino [Inf. 32-33], the "girone" or circle of the proud [Purg. 10-12], the encounter with Buonagiunta da Lucca [Purg. 10-12], the return of Beatrice and departure of Virgil [Purg. 30], the meeting with his ancestor Cacciaguida [Par. 15-17], and so on), often makes it hard to discern the arc of the poem as a whole. One of the efforts that I appreciate is the effort in current criticism to focus more attention than is usual on multi-canto sequences (such as that leading from Purgatorio 16 to 27 ).${ }^{10}$ In my teaching I try to do the same, although it is trickier business, since it involves delving deeper than most of my undergraduates and even some of my graduates would like into the arcana of scholasticism, the politics of Guelf vs. Ghibelline, the economics of proto-capitalist Florence, and so on.

At least as tricky is the problem of connecting the experiences of the three different realms in a way that brings out both the immense scope and incredible specificity of Dante's poem. Of course, one should be as clear as possible, with outlines, diagrams, pictorial representations, and so on about the ordering principles of divisions and subdivisions that structure each of the canticles, and the ways in which these are mirrored and reversed from realm to realm. And the recent development of the old principle of "vertical" readings promoted by the Oxford group, which emphasizes the parallels between same-numbered cantos of the successive canticles is useful (for instance the parallel cantos 6 for Dante's politics; the fiery rhetoric that links the cantos 26-27 in each realm, etc.). Useful as this technique may be, however, it actually glosses over the complexities by which Dante connects canto to canto (sometimes the principle is one of reversal [e.g., Inf. 5, Purg. 27; Purg. 5, Inf. 27], and it gets more elaborate and less predictable). ${ }^{11}$

What I would like to do in the balance of my time, then, is single out a series of episodes over the three canticles that track, on the one hand, the "secular" pattern of poetic self-authorization that has been most prominent in my own work and in much North American Dante criticism of the last half-century, and, on the other, the narrative of the spiritual evolution of Dante-pilgrim and the quasi-evangelical mission of Dante-poet on the other. In doing this, I will not add much to what others and I myself have said about these specific episodes—my aim, instead, is to suggest a guiding thread that might be useful in the teaching of the Commedia. Let me begin by recalling the fundamental discovery of Robert Hollander that was one of the initial inspirations for my own study of Dante's evolving relationship to medieval categories of authorship and authority. Hollander noticed that word "autore," which Dante defines in one acceptation as "a person worthy of faith and obedience"

10 For this particular sequence, see Ascoli, Dante and the Making, pp. 332-57. Among the rare, comprehensive efforts of this kind, see (Swing 1962; Cogan 1999).

11 (Corbett and Webb [2015] 2017). The most notorious example, widely discussed in the literature are the parallel cantos 6, which move in scope from Florence (Inferno), to Italy (Purgatorio), to the Holy Roman Empire (Paradiso). Other excellent examples are in (Fido 1986); and the "Intercantiche" by Durling and Martinez in the second volume (Purgatorio) of the Durling translation cited above. 
(qualities linked by him to Aristotle in his treatise, Convivio [The Banquet], book 4, chp. 6; translation mine), appears exactly two times in the Divine Comedy, once attributed to Virgil, whom Dante-pilgrim calls "lo mio maestro e 'l mio autore" (Inf. 1.85: my master [or teacher] and my author) in the first canto of Inferno, and once to God, whom he refers to as the "verace autore" (Par. 26.40: "the truthful [or veracious] Author"), in Paradiso 26. ${ }^{12}$ With these references are associated three mentions of the word "autorità" - once in reference to the great pagan thinkers, poets and rulers gathered together in Limbo, Virgil's eternal dwelling place (Inf. 4.113)—and twice to the rational, human authority that bolsters Dante's understanding of the divine love of the True Author, again in Paradiso 26 (1l. 26, 47). The conceptual and narrative arc described by Hollander begins with Dante modeling himself on and measuring himself against the poetic and intellectual authority of the pagan ancients, and ends with him conceding that the source of all authority and the one true author of truth itself is God, in effect renouncing his own claim to being an "author" even as he goes far beyond Aristotle, Virgil, and indeed most Christian writers in his assertion of access to the divine. To Hollander's account I have added, among other things, the consideration that for Dante in the Divine Comedy the word "autore" reflects both of his earlier etymological definitions of the word, not only of the philosopher "worthy of faith and obedience" but also of the poet (autore from avieo), who binds together, in effect creates, language, in particular the illustrious vernacular of Italy, with the form-endowing use of meter and rhyme. ${ }^{13}$

In the three episodes I will now consider, I will focus primarily not on either of the previously mentioned roles of Dante-pilgrim, namely as witness of the destiny of souls or exclusively as pupil of Virgil, Beatrice and/or Bernard, but rather on their special character as episodes in which Dante becomes part of a small group or community into which he is inducted in such a way as to constitute a special moment of "authorization" that will then allow him to accede to the next such encounter, and so on. While there are other "personalized" encounters, these three stand out not only in and of themselves, but in the ideal, ascending pattern that they create as the pilgrim moves upward and comes closer and closer not only to his own climactic spiritual experience as character, but also to becoming the poet who can then recount that experience. These episodes are: the meeting with the five classical poets in Inferno 4; the encounter of Virgil and Dante with the late classical epic poet Statius in Purgatorio 20-22; and the "examination scene" in the Heaven of the fixed stars in which Dante is tested in turn by Saints Peter, James, and John on the three theological virtues (respectively, Faith, Hope and Divine Love) and then meets with our first ancestor, Adam, in Paradiso cantos 24-26.

I will not dwell at length on the first of these scenes, which is by far the best known of them. ${ }^{14}$ You may recall that in Canto 4 Dante enters the first circle of Hell, the Limbo, or outer-edge, where, to quote Virgil, "sanza speme vivemo in disio" (Inf. 4.42; without hope we live in desire). Those included in Limbo are the unbaptized (especially infants) and those who, living before Christ, and of course also unbaptized, did not believe sufficiently to be redeemed. Also noted is the fact that before the "Harrowing of Hell" after Christ's Crucifixion, this place had been populated by Old Testament Patriarchs and women, beginning with Adam, who Christ then took back with him to Heaven (note, by the way, the anticipation both of Dante's entrance into Adam's first home at the end of the Purgatorio [cantos 28-33], and of his meeting with Adam in Paradiso 26). While there is no evident punishment for the denizens of this first circle except deprivation of the Divine Presence, it is also the case that their hopelessly desiring condition, rooted in their lack of faith in the one true God, is in fact the basis for every punishment suffered throughout Hell, a point that may be helpful in orienting students. Most noteworthy for the teaching of this particular configuration, of course, is the fact that Dante is incorporated into the band, the "bella scola," of five classical poets (in addition to Virgil: Homer, Horace, Ovid, and Lucan),

12 Hollander, Allegory, pp. 78-79.

13 Ascoli, Dante and the Making, esp. chps. 1-2, and chp. 7, sec. v-vi. See also Mazzotta, Dante, Poet of the Desert, pp. $258-59$.

14 See for instance, Hollander, Il Virgilio dantesco; Barolini, Dante's Poets; (Iannucci 1993). 
Così vid'i' adunar la bella scola di quel signor de l'altissimo canto che sovra li altri com'aquila vola.

Da ch'ebber ragionato insieme alquanto, volsersi a me con salutevol cenno, e '1 mio maestro sorrise di tanto; e più d'onore ancora assai mi fenno, ch'e' sì mi fecer de la loro schiera, sì ch'io fui sesto tra contanto senno.

Così andammo infino a la lumera, parlando di cose che ' 1 tacere è bello, sì com'era 'l parlar colà dov'era. (Inf. 4. 94-105). (So saw I come together the lovely school of that lord of highest song [Homer], who soars above the others like an eagle. When they had spoken together for a time they turned to me with sign of greeting, and my master smiled at that; and they did me an even greater honor, for they made me one of their band, so that I was sixth among so much wisdom. Thus we went as far as the light, speaking things of which it is good to be silent now, as it was good to speak them there where I was).

That Dante becomes the "sesto"—-sixth or last or both—among such (poetic) wisdom, will again suggest both humility and self-affirmation, and it is evident that as the "sesta compagnia in due si scema" (Inf. 4.148: the company of six is reduced to two), when Dante-pilgrim, with Virgil, move on down to the next circle of Hell, Dante, as poet, has already moved beyond the spiritual limitations that constrain the other five, including, in the long, in fact endless, run, Virgil as well, to Limbo.

The most prominent purgatorial sequel to this episode, again as is well-known, is the encounter in Cantos 21-22 (and following) with Statius, late-classical author of the Thebaid and the unfinished Achilleid, who lived after the coming of Christ, but apparently was not known to have been a Christian before Dante represents him as such in this episode. ${ }^{15}$ Statius first appears to the travelers just as he experiences a Christo-mimetic liberation from the bonds of Purgation, which enables him to proceed freely up through the last two "gironi" (circles or terraces), those of gluttony and lust, of which he was apparently not guilty in any way. As the one purging sinner in the whole canticle who is seen passing from one zone to another, he embodies the fundamental difference between the eternal punishments of Hell and the temporary, if still intense, tortures of Purgatorio. The only other person seen passing these boundaries is, of course, Dante himself, and so there is an immediate identification between Statius and the pilgrim.

The episode, on the other hand, apparently focuses primarily on the interactions between Statius and Virgil, with explicit and repeated echoing of the "bella scola" of Inferno 4, which this grouping at once reproduces and revises. The first of the paired cantos provides an identification of the two classical poets, and leads to the constitution of a relationship of friendship between them, mediated by Dante's inability to conceal from Statius the fact that his guide is the author of the Aeneid, of which Statius has just said that it was "my mama and my nurse in writing poetry" (Purg. 21.97-98), a declaration that also aligns him with Dante's original identification of Virgil as his "master and author." These cantos systematically intertwine questions concerning the special role of "poet" and those concerning Christian faith or lack thereof. The presence of all three of the members of this little group in Purgatory requires explanation. Virgil requires it, because he is a damned soul consigned to the Limbo of virtuous pagans and clearly has no business being outside of Hell. Dante needs it as well because, as is repeatedly stressed throughout the canticle, the fact that he is still "in the body" makes him unlike all of the

15 For Dante, Virgil and Statius, see among many others: Mazzotta, Dante, Poet of the Desert, pp. 219-25; Barolini, Dante's Poets, pp. 256-69; (Martinez 1995) (one of his several important essays on this figure); (Wetherbee 2008, chp. 6). 
disembodied shades who populate this realm, and is in need of special guidance provided by grace (even if as Virgil says, it is clear that he must "reign with the good" after his death). Finally, Statius' presence requires explanation because there is no trace in the books that Virgil has somehow read or for that matter in the historical record known to Dante that he had ever converted to Christianity. It is, of course, Statius's account of his double conversion, both away from the vice of excessive spending (symmetrical with avarice in the Aristotelian scheme), and (albeit secretly) toward the new Christian religion, and the role that Virgil and his texts played in those alterations that dominates the second of the two cantos, most notably in the following lines:

$$
\begin{aligned}
& \text {. . . . . “Tu prima m'invïasti } \\
& \text { verso Parnaso a ber ne le sue grotte, } \\
& \text { e prima appresso Dio m'alluminasti. } \\
& \text { Facesti come quei che va di notte, } \\
& \text { che porta il lume dietro e sé non giova } \\
& \text { ma dopo sé fa le persone dotte, } \\
& \text { quando dicesti: 'Secol si rinnova; } \\
& \text { torna giustizia e primo tempo umano, } \\
& \text { e progenïe scende da ciel nova.' } \\
& \text { Per te poeta fui, per te cristiano." (22.64-73) }
\end{aligned}
$$

("You first sent me to Parnassus to drink from its springs, and you first lit the way for me toward God. You did as one who walks at night, who carries the light behind him and does not help himself, but instructs the persons coming after, when you said 'The age begins anew; justice returns and the first human time, and a new offspring come down from heaven.' Through you I became a poet, through you, a Christian").

What emerges is a kind of chiastic conundrum. One poet is a damned pagan, the other a saved Christian, but the former's poetry is capable of revealing, or at least supporting, Christian revelation, while the latter's poetry shows no trace of Christian inspiration. Subtending the episode is a supporting rationale for Virgil's role throughout the first two realms of the afterlife, namely that God is capable of speaking through him in ways that he himself does not and cannot recognize, a corollary of the general dictum that divine providence always works in ways mysterious to human beings. What is left unspoken, though it is structurally obvious already in the episode, and will only become more so as the pilgrim ascends first into the earthly paradise and thence through the visible heavens into the Empyrean, is that, of the three, Dante alone is both a Christian and the author of a Christian poem. ${ }^{16}$ Once again Dante becomes part of a community of writers, clearly cast as the last and least in dramatic terms; although, once again, it is implicitly obvious that the last will be first.

This conflation of Dante's spiritual itinerary and his poetic vocations in dialectical relation to Virgil and Statius will become particularly clear in his final interaction with his newly multiplied guides, when, in canto 28, lines 139-148, Matelda explains to him that Parnassus, the classical mountain of poetic inspiration, was a dream-like foreshadowing of the Earthly Paradise he is about to enter:

\footnotetext{
“Quelli ch'anticamente poetaro

l'età dell'oro e suo stato felice, forse in Parnaso esto loco sognaro.

Qui fu innocente l'umana radice;

qui primavera sempre e ogne frutto;
}

16 See the reading of this episode in Ascoli, Dante and the Making, pp. 317-22, which draws significantly on the interpretations of Mazzotta, Barolini, and Martinez, cited in the previous note. 
nettare è questo di che ciascun dice."

Io mi rivolsi 'n dietro allora tutto

a' miei poeti, e vidi che con riso

udito avëan l'ultimo costrutto" (Purg. 28.139-47; cf. 31.139-45)

("Those who in ancient times wrote in their poetry of the Age of Gold and its happy state, perhaps [in or through] Parnassus dreamed [of] this place. Here the human root was innocent; here there is always spring and every fruit; this is the nectar of which each one tells." I turned entirely around, back to my poets, then, and I saw that they had smiled hearing her last construction).

The Eden which Dante then enters then becomes a place where, at least in my reading, Dante imagines his invention of the vernacular poetic language capable of being molded into the Commedia as an analogue to the formation of human speech by the first man, Adam. ${ }^{17}$

In the final entry in this series of Dante's inductions into the company of writers, the cast of characters is very different than the two I have examined so far. Yes, they are writers, but not of poetry: rather all are sainted souls who were apostles on earth, the three favored apostles of Jesus in fact, those who, among other things, participated in the Transfiguration that revealed Jesus as the Christ in the company of the Old Testament authors and prophets; ${ }^{18}$ all three are authors of New Testament Epistles, one is the author both of a Gospel and of Revelation. ${ }^{19}$ And, although in the narrative order of the canticle Dante does leave them behind him, at least temporarily, there is certainly no question of his "superseding" them as he does with the pagan poets and Statius. However, as we shall see, it is clear enough that he is becoming something like their equal. And in the background, alluded to but never met in person, lurks the New Testament author with whom Dante invited comparison from the very outset, St. Paul, said to be the possessor of a "verace stilo" (Par. 24: truthful stylus [but also "style"] - echoing and improving on the "bello stilo" [truthful style] Dante was said to have inherited from Virgil in Inf. 1.87), whose journey to the "third heaven" Dante certainly has overgone by this point, at least in detail, if not in spiritual import.

But I am getting ahead of myself. I would begin teaching this episode by setting the stage for what I have punningly referred to as Dante-pilgrim-poet's "starring" role. The episode that concerns us specifically spans Paradiso Cantos 24-26, but it is part of the larger suite of cantos devoted to Dante's passage through the Ptolomaic Heaven of the fixed stars, the $8^{\text {th }}$ and last of the visible Heavens, followed only by the Primum Mobile and the Empyrean, the invisible Heaven of Heavens itself. The episode begins at line 100 (always a significant number for Dante) of Canto 22, and lasts for the final third of the canto (ending at 154). It then continues through Cantos 23-26 entire, and occupies almost the first two thirds (lines 1-96) of Canto 27's 148 lines. At approximately 5 cantos in length it is the longest stay in any single subdivision of Paradiso, and indeed the longest single stretch in one place in the entirety of the Commedia (or tied with the earthly paradise episode, depending on whether you count the time Dante spends on the outside looking in). It is also the episode in which Dante-pilgrim himself is the center of attention for the longest time. The reason is not far to seek. Dante's sojourn in the Heaven of fixed stars occurs in one specific constellation, Gemini, which, he hastens to tell us, is his natal constellation, and its angelic influence, mediating the will of divine providence, has made him

17 Ascoli, Dante and the Making, pp. 400-5, and see also the related argument concerning On Eloquence in the Vernacular, in chp. 4, and concerning The Banquet (Convivio) in the essay by the same author (Ascoli 2018).

18 The Transfiguration of Christ is told in Matthew 17: 1-9, Mark 9: 1-9, and Luke 9: 28-36. In a famous simile (Purg. 32.76-82), Dante compares himself to the three privileged Apostles who witness the event; in his earlier Convivio (book 2, chp. 1) he used the scene to illustrate the "tropological" or "moral" sense of fourfold allegory. On Dante's use of and identification with the scene of the Transfiguration, see (Schnapp 1986, pp. 91-123; Hawkins 1999, pp. 186-93).

19 At this point, let me mention a couple of the many studies dedicated in part or as whole to Dante's use of the Bible in the Commedia: (Barblan 1988); Hawkins, Dante's Testaments, esp. chps. 1-4; (Kleinhenz 2015, chps. 6, 7, 17). For the related question of the analogies between the author of the Commedia and the the human authors of the Bible, see again note 4 above, as well as (Ascoli 2017). 
the one (and apparently only) person worthy both of taking this extraordinary journey, in or out of the body, and of then writing the work in which what he can recall of his travels is recorded:

S'io torni mai, lettore, a quel divoto trïunfo per lo quale io piango spesso le mie peccata e ‘l petto mi percuoto: tu non avresti in tanto tratto e messo nel foco il dito, in quant' io vidi ' 1 segno che segue il Tauro e fui dentro da esso. O gloriose stelle, o lume pregno di gran virtù, dal quale io riconosco tutto, qual che si sia, il mio ingegno, con voi nasceva e s'ascondeva vosco quelli ch'è padre d'ogne mortal vita, quand' io sentì di prima l'aere tosco; e poi, quando mi fu grazia largita d'entrar ne l'alta rota che vi gira, la vostra regïon mi fu sortita.

A voi divotamente ora sospira l'anima mia, per acquistar virtute al passo forte che a sé la tira.

Col viso ritornai per tutte quante le sette spere...

[e] tutti e sette mi si dimostraro quanto son grandi e quanto son veloci e come sono in distante riparo.

L'aiuola che ci fa tanto feroci, volgendom' io con li etterni Gemelli, tutta m'apparve da' colli a le foci.

Poscia rivolsi li occhi a li occhi belli. (Par. 22.106-123, 133-134, 148-154)

(So may I return, reader, to that devout triumph on whose account I ever weep for my sins and beat my breast: you would not any sooner have withdrawn your finger from the fire and put it in, than I saw the sign that follows the Bull and was within it. O glorious stars, $\mathrm{O}$ light pregnant with great power, from which I acknowledge that all my talent comes, whatever it may be, with you was being born and with you was setting he that is father of every mortal life, when I first felt the Tuscan air, and then, when grace was extended to me to enter the high wheel that turns you, your region was allotted me. To you now my soul devoutly sighs, to acquire power for the difficult pass that draws me to itself. ... With my sight I returned through every one of the seven spheres ... And all the seven showed me how large they are and how swift and how distant in dwelling. The little threshing floor that makes us so ferocious, as I was turning with the eternal Twins, appeared to me, all of it from the mountains to the river mouths. Then I turned my eyes back to her [Beatrice's] lovely eyes).

From this vantage point he looks back over the entirety of his journey, down through the seven planets of the geocentric cosmos, even to the "threshing floor" of our world, a sight that he will, with punctual symmetry, reproduce at the moment when he finally leaves this sphere for the Primum Mobile. ${ }^{20}$

20 For a reading of the episode of the Fixed Stars as a whole, which has influenced my own thinking considerably, see (Durling and Martinez 1990, pp. 240-58) (Martinez is the principal author of these pages). 
Each of those earlier spheres housed (if only for appearance's sake) ${ }^{21}$ different qualities of saved souls, from lowest (those who failed to keep vows, in the Heaven of the Moon), to highest (the contemplatives of the 7th heaven, Saturn). This sphere, however, is the seat of the Church Triumphant in it its entirety, though the only souls to appear to Dante here are the most illustrious of all, this side of Mary and Christ himself, namely Saints Peter, James, and John, and Adam, father of all humanitity, the first three of whom test Dante's worthiness to be "of their number," and the last of whom offers his conversation as a kind of reward for the successful passing of that test. In other words, once again, Dante is at once subordinated and assimilated to a very distinguished group of souls.

In this case, conspicuously, the interactions would seem to be of a theological rather than a poetic kind. Dante undergoes a formal, tripartite examination that, as he says, is analogous to the scholastic ritual of the "bachelor" being tested to determine his worthiness to be granted the title of "magister" or "maestro," which we recall is also the second and lesser of the two epithets Dante attributes to Virgil in Canto one, Inferno (but which here is clearly in regards to a material entirely alien to the pagan poet, namely the three theological virtues named by Saint Paul):

Sì come il bacciallier s'arma e non parla

fin che 'l maestro la question propone,

per approvarla, non per terminarla,

così m'armava io d'ogne ragione

mentre ch'ella dicea, per esser presto

a tal querente e a tal professione. (Paradiso 24.46-51)

(And as the bachelor arms himself but does not speak until the master proposes the question, and then to analyze, not to determine it; so I armed myself with all reasons while she

[Beatrice] was speaking, to be ready for such a questioner and such a profession).

The pilgrim then goes on first to define, then to prove the existence of, and finally to demonstrate his own possession of Faith to St. Peter in Canto 24, of Hope to St. James in Canto 25, and of Charity or holy Love to St. John in Canto 26. And while the examination in Faith is, strictly speaking, theological, it may well recall Statius' discourse on his accession to faith (albeit in Nicodemian mode) in Purgatorio 22, since, as we have just seen, the reference to Paul's "verace stilo" clearly recalls and supersedes Virgil's "bello stilo." Perhaps most important as a key to making a connection between Canto 24 and the earlier episode is the fact that where Statius famously tries and fails three times to embrace the empty shade of Virgil, St. Peter celebrates Dante's success by circling him three times at canto's end (24.152), as he had also greeted Beatrice at the beginning of the canto (24.19-24).

I have written much more extensively elsewhere about the three examinations and the various ways in which they authorize Dante and his language (specifically the vernacular language in which he is writing the Divine Comedy). ${ }^{22}$ In the remainder of this essay, however, I would simply like to point to some fairly obvious ways in which a student can be made to see how the examination scene, and Dante's indoctrination into the "Church Triumphant," even as he is given his marching orders for a return to the "Church Militant," make explicit the role of Christian poet par excellence distantly anticipated in Inferno 4, and that Dante implicitly occupied in Purgatorio 21 and 22, and then more explicitly assumed on his entrance into the Earthly Paradise.

21 The distribution of the sainted souls throughout the visible heavens is actually a fiction designed ad hoc for Dante, since they are all really in the Empyrean: see Freccero, The Poetics of Conversion, chp. 14.

22 Ascoli, Dante and the Making, chp. 7, sections v-vi and see again n. 17 above. On aspects of this episode, see also (Brownlee 1984; Brownlee 1990); William Stephany, "Paradiso XXV," in "Dante's 'Divine Comedy'; Introductory Readings III: 'Paradiso'," a special issue of Lectura Dantis 16-17 (Stephany 1995, pp. 371-88; Benfell 1992); Barolini, The Undivine Comedy, chp. 10; Hawkins, Dante's Testaments, chp. 4; (Moevs 1999; Lombardi 2007, pp. 129-34, nn). 
As has regularly been remarked, Dante, who in Inferno twice called his poem a "comedia" (16.128; 21.2), in clear opposition to Virgil's "alta tragedia" (Inf. 19.113) in this specific episode apparently tries out a new sort of name, beginning already in Canto 23:

Se mo sonasser tutte quelle lingue

che Polimnïa con le suore fero

del latte lor dolcissimo più pingue,

per aiutarmi, al millesmo del vero

non si verria, cantando il santo riso

e quanto il santo aspetto facea mero;

e così, figurando il paradiso,

convien saltar lo sacrato poema,

come chi trova suo cammin riciso.

Ma chi pensasse il ponderoso tema

e l'omero mortal che se ne carca,

nol biasmerebbe se sott' esso trema:

non è pareggio da picciola barca

quel che fendendo va l'ardita prora,

né da nocchier ch'a sé medesmo parca. (Paradiso 23.55-69)

(If now were to sound all those tongues which Polyhymnia and her sisters with their sweetest milk made richest to help me, we could not come within a thousandth of the truth, singing her holy smile and how bright it made her holy face, and thus, figuring forth Paradise, the consecrated poem must leap over, like one who finds his path cut off. But whoever thinks of the ponderous theme and the mortal shoulder that has taken it on, will not blame it for trembling beneath the burden: it is no voyage for a little bark, the one my daring prow goes cutting, nor for a helmsman who spares himself).

The poem now is "consecrated," and then in the first line of canto 25 Dante refers to his work in progress as a "poema sacro," a holy poem, to which both Heaven and Earth have put their hands, and imagines himself returning from exile to his beloved and despised Florence to receive the laurel crown in the Baptistry:

Se mai continga che ‘l poema sacro, al quale ha posto mano e Cielo e terra

sì che m'ha fatto per più anni macro, vinca la crudeltà che fuor mi serra del bello ovile ov' io dormì agnello, nimico ai lupi che li danno guerra, con altra voce omai, con altro vello ritornerò poeta, $\mathrm{e}$ in sul fonte del mio battesmo prenderò 'l cappello; però che ne la fede, che fa conte l'anime a Dio, quivi intra' io, e poi Pietro per lei sì mi girò la fronte. (Paradiso 25.1-12)

(If it ever happen that the sacred poem, to which both Heaven and earth have set their hand, so that for many years it has made me lean, vanquish the cruelty that locks me out of the lovely sheepfold where I slept as a lamb, an enemy of the wolves that make war on it, with another voice by then, with other fleece I shall return as poet, and at the font of my baptism I shall accept the [laurel] wreath: for there I entered the faith that makes souls known to God, and later Peter so circled my brow because of it). 
The idea of a consecrated or holy poem, doubly acknowledged by the classical laurel and St. Peter's symbolic crowning, clearly realizes the promise of the Statius/Virgil episode, which in fact concluded in Canto 22 with a reference to John the Baptist, and may in fact, and ironically, recall Virgil's eternal home, shared with unbaptized infants and his fellow virtuous pagans who were not, like Dante, born into the faith of Peter. That these lines end at almost the exact center of the episode of the Gemini episode (there are 360 lines through 25.12, and 361 more before Dante and Beatrice leave the constellation), no doubt emphasizes the fact that Dante's examination in theology is also proof of his fitness as holy poet, comparable, perhaps, to the David of the Psalms, whose "teo-dia, or "god-song," the pilgrim will shortly thereafter cite in the examination on hope (25.73), with a distant echo of the apparently now superseded categories of "come-dìa" and "trage-dìa" (see also Par. 30.24).

In some sense, then, we have clearly arrived at Hollander's "theologus-poeta." But perhaps there is a little more to say. The reference to the collaboration of "heaven and earth" has, no doubt rightly, been taken as a hint at a double authorship, human and divine, not unlike that of the Bible itself. But it also has a special significance in the context of the Gemini, the twins, who are, of course, Castor and Pollux, the twin sons of Leda by Jupiter, who famously took turns in heaven and in hell, expressing their dual human and divine origins, and, in a way, anticipating Dante's journey through Hell to Paradise. ${ }^{23}$ In this sense, the whole episode suggests that it is Dante in himself who, Christo-mimetically, has realized the possibility for humanity to fully actualize its divinely endowed nature. In this sense, too, it is particularly fitting that the examination scene leads into Dante's encounter with Adam, in which humanity's "first father" makes reference to his own itinerary that led him from Eden, to the fallen world of history, to the underworld - the Limbo where Virgil dwells eternally (this is the last mention of him in the Divine Comedy ) - before being elevated at last to the "concilio" of the blessed:

Tu vuogli udir quant' è che Dio mi puose

ne l'eccelso giardino ove costei

a così lunga scala ti dispuose,

e quanto fu diletto a li occhi miei,

e la propria cagion del gran disdegno,

e l'idioma ch'usai e che fei.

Or, figliuol mio, non il gustar del legno

fu per sé la cagion di tanto essilio,

ma solamente il trapassar del segno.

Quindi onde mosse tua donna Virgilio,

quattromilia trecento e due volumi

di sol desiderai questo concilio,

e vidi lui tornare a tutt'i lumi

de la sua strada novecento trenta

fiate mentre ch'io in terra fu'mi. (Paradiso 26.109-120)

(You wish to know how long ago God placed me in the high garden where she [Beatrice] there readied you for so long a stairway, and how long it was a delight to my eyes, and the true reason for his great anger, and the language that I spoke and that I devised. Now, my son, not the tasting of the tree in itself was the cause of so long an exile, but only the going beyond the [sign]. Down there whence your lady sent Virgil, for four thousand, three hundred and two turnings of the sun I yearned for this assembly [the time between his death

23 For an extended reflection on the significance of the Gemini for Dante, with a different emphasis from mine, see Durling and Martinez, Time and the Crystal, pp. 240-57 et passim. On Dante's astronomy/astrology more generally, see (Kay 1994; Cornish 2000). 
and Christ's], and I saw him return along the road of all his lights nine hundred thirty times, while I lived on earth).

Like Adam, and Christ, like the Twins, Dante has gone from this world to the underworld and on to Heaven, and in so doing has achieved the capacity to write this "consecrated poem," in which, as we have seen, he will assume the starring role.

Funding: This research received no external funding.

Conflicts of Interest: The author declares no conflict of interest.

\section{References}

Ascoli, Albert Russell. 2008. Dante and the Making of a Modern Author. Cambridge: Cambridge University Press. Ascoli, Albert Russell. 2013. Poetry and Theology. In Reviewing Dante's Theology. Edited by Claire Honess and Matthew Treherne. 2 vols. Bern: Peter Lang, vol. 2, pp. 3-42.

Ascoli, Albert Russell. 2017. Performing Salvation in Dante's Commedia. Dante Studies 135: 74-105. [CrossRef]

Ascoli, Albert Russel. 2018. 'Ponete mente almen come sono bella': Poetry and Prose, Goodness and Beauty, in Dante's Convivio. In Dante's 'Convivio': Or, How to Restart a Career in Exile. Edited by Franziska Meier. New York: Peter Lang, pp. 115-44.

Barblan, Giovanni, ed. 1988. Dante e la Bibbia. Florence: Olschki.

Barolini, Teodolina. 1984. Dante's Poets: Textuality and Truth in the Commedia. Princeton: Princeton University Press. Barolini, Teodolinda. 1992. The Undivine Comedy: Detheologizing Dante. Princeton: Princeton University Press.

Barolini, Teodolina. 2006. Dante and the Origins of Italian Literary Culture. New York: Fordham University Press. Benfell, V. Stanley. 1992. Biblical Truth in the Examination Cantos of Dante's Paradiso. Dante Studies 115: 89-110. Brownlee, Kevin. 1984. Why the Angels Speak Italian: Dante as Vernacular Poeta in Par. XXV. Poetics Today 5: 597-610. [CrossRef]

Brownlee, Kevin. 1990. Paradiso XXVI. Lectura Dantis 6: 46-59.

Cogan, Marc. 1999. The Design in the Wax. Notre Dame: University of Notre Dame Press.

Contini, Gianfranco. 1976. Dante come personaggio-poeta della Commedia. In Un'idea di Dante. Turin: Einaudi, pp. 33-62. First published 1957.

Corbett, George, and Heather Webb, eds. 2017. Vertical Readings in Dante's Comedy. 3 vols. Cambridge: Open Book Publishers. First published 2015.

Cornish, Alison. 2000. Reading Dante's Stars. New Haven: Yale University Press.

Cornish, Alison. 2011. Vernacular Translation in Dante's Italy. Cambridge: Cambridge University Press.

Durling, Robert M., ed. 2011. Robert M. Durling, trans. The Divine Comedy of Dante Alighieri. 3 vols. Commentary by Robert M. Durling and Ronald L. Martinez; Illustrated by Robert Turner. Oxford and New York: Oxford University Press. First published 1996.

Durling, Robert M., and Ronald L. Martinez. 1990. Time and the Crystal. Berkeley and Los Angeles: University of California Press.

Eliot, Thomas Stearns. 1964. Dante. In Selected Essays. New York: Harcourt-Brace, pp. 199-237. First published 1929.

Fido, Franco. 1986. Writing like God, or Better?-Symmetries in Dante's 26th and 27th Cantos. Italica 63: 250-64. [CrossRef]

Freccero, John. 1986. Dante: The Poetics of Conversion. Cambridge: Harvard University Press.

Hawkins, Peter. 1999. Dante's Testaments: Essays in Scriptural Imagination. Stanford: Stanford University Press.

Hollander, Robert. 1980. Dante as Theologus-Poet. In Studies in Dante. Ravenna: Longo, pp. 39-89. First published 1976.

Hollander, Robert. 1969. Allegory in Dante's Commedia. Princeton: Princeton University Press.

Hollander, Robert. 1983. Il Virgilio dantesco: tragedia nella Commedia. Florence: Olschki.

Iannucci, Amilcare, ed. 1993. Dante e la 'bella scola' della poesia: Autorità e sfida poetica. Ravenna: Longo.

Jacoff, Rachel, ed. 2007. The Cambridge Companion to Dante, 2nd ed. Cambridge: Cambridge University Press.

Jacoff, Rachel, and Jeffrey T. Schnapp, eds. 1991. The Poetics of Allusion: Virgil and Ovid in Dante's Commedia. Stanford: Stanford University Press. 
Kablitz, Andreas. 1999. Poetik der Erlösung. Dantes Commedia als Verwandlung und Neubegründung mittelalterlicher Allegorese. In Commentaries-Kommentare. Edited by Glenn Most. Göttingen: Vandenhoeck \& Ruprecht, pp. 353-79.

Kay, Richard. 1994. Dante's Christian Astrology. Philadelphia: University of Pennsylvania Press.

Kleinhenz, Christopher. 2015. Dante Intertestuale e Interdisciplinary. Ariccia: Aracne.

Le Goff, Jacques. 1986. The Birth of Purgatory. Translated by Arthur Goldhammer. Chicago: University of Chicago Press.

Lombardi, Elena. 2007. The Syntax of Desire: Language and Love in Augustine, the Modistae, Dante. Toronto: University of Toronto Press.

Martinez, Ronald L. Martinez. 1995. Dante and the Two Canons: Statius in Virgil's Footsteps (Purgatorio 21-30). Comparative Literature Studies 32: 151-75.

Mazzotta, Giuseppe. 1979. Dante, Poet of the Desert. Princeton: Princeton University Press.

Mazzotta, Giuseppe. 1993. Dante's Vision and the Circle of Knowledge. Princeton: Princeton University Press.

Mazzotta, Giuseppe. 2008. Reading Dante. New Haven: Yale University Press.

Moevs, Christian. 1999. Miraculous Syllogisms: Clocks, Faith, and Reason in Paradiso 10 and 24. Dante Studies 117: 59-84.

Regn, Gerhard. 2007. Double Authorship: Poetic and Prophetic Authorship in Dante's Paradiso. MLN 122: 167-85. [CrossRef]

Schnapp, Jeffrey. 1986. The Transfiguration of History at the Center of Dante's Paradise. Princeton: Princeton University Press.

Steinberg, Justin. 2007. Accounting for Dante Urban Readers and Writers in Late Medieval Italy. Notre Dame: University of Notre Dame Press.

Steinberg, Justin. 2013. Dante and the Limits of the Law. Chicago: University of Chicago Press.

Stephany, William. 1995. Paradiso XXV. Lectura Dantis 16-17: 371-88.

Swing, T. K. 1962. The Fragile Leaves of the Sybil: Dante's Master Plan. Westminster: The Newman Press.

Wetherbee, Winthrop. 2008. The Ancient Flame: Dante and the Poets. Notre Dame: University of Notre Dame Press.

(C) 2019 by the author. Licensee MDPI, Basel, Switzerland. This article is an open access article distributed under the terms and conditions of the Creative Commons Attribution (CC BY) license (http://creativecommons.org/licenses/by/4.0/). 